\title{
Bezpečnostní politika fotbalového mistrovství Evropy 2012
}

\section{Security policy for the European Football Championship 2012}

\author{
Lukáš Morys, Josef Smolík
}

Fakulta sociálních studií Masarykovy univerzity v Brně

\begin{abstract}
Abstrakt:
Př́spěvek se zabývá bezpečnostni politikou fotbalového mistrovství Evropy 2012, které se konalo v Polsku a na Ukrajině. Cílem studie je identifikovat nejzávažnější bezpečnostní rizika vyplývající z konání EURO 2012 a objasnit, jaké bezpečnostni postupy a strategie zvolily pořadatelské země, aby zajistily bezpečný šampionát. Článek mapuje také průběh evropského šampionátu z hlediska bezpečnosti.
\end{abstract}

\section{Abstract}

This paper deals with security policy for the European Football Championship 2012 held in Poland and Ukraine. The aim of this study is to identify the most serious security risks arising from the holding of EURO 2012 and to clarify what security procedures and strategies were chosen by the host countries to ensure safe championship. The article also monitors the course of the European Championship in terms of security.

Klíčová slova: bezpečnostní politika, EURO 2012, fotbal, chuligánství, terorismus, Polsko, Ukrajina

Key words: security policy, EURO 2012, football, hooliganism, terrorism, Poland, Ukraine

\section{ÚVOD}

Velké sportovní akce se v poslední době staly hlavními světovými událostmi, jež mají kromě sportovního hlediska také obrovský ekonomický, politický, kulturní, mediální a sociální význam. Města a národy intenzivně soutěží o právo pořádat velké akce typu olympijských her nebo mistrovství světa či Evropy ve fotbale i v dalších sportech. Uchazeči si jsou vědomi, že pořádaní velkých sportovních akcí přináší hostitelským městům či zemím výhody, mezi které patří např. zvýšení př́imů z cestovního ruchu či investice do infrastruktury. S velkými sportovními akcemi souvisí také negativní projevy, které se vyskytují v podobě korupce, rasismu, zvýšené míry kriminality, násilí a zvýšení výskytů sociálněpatologických jevů (prostituce, nárůst spotřeby drog) atp. (srov. Frosdick \& Marsh, 2005; Giulianotti \& Klauser, 2010; Bedřich, 2006; Sekot, 2007). V posledních desetiletích se do popředí dostává otázka zajištění bezpečnosti těchto sportovních událostí (NPIA, 2010).

Již od mnichovského incidentu, který se udál v průběhu olympijských her v roce 1972, se jednou z hlavních otázek při plánování a pořádání velkých sportovních akcí stala bezpečnost. Zejména v období po 11. září 2001 pak rostoucí výdaje na zajištění bezpečnosti demonstrovaly intenzivnější propojení velkých sportovních akcí a bezpečnostní problematiky (viz Giulianotti \& Klauser, 2010; Liedel \& Piasecka, 2012). V oblasti sportu především s fotbalovými zápasy - se dostává do popředí i otázka bezpečnostního managementu (Frosdick \& Marsh, 2005, s. 180-182).

Základním cílem této studie je podat ucelený přehled o bezpečnostní politice při fotbalovém mistrovství Evropy 2012. Hlavním metodickým východiskem pro tento text je deskripce jednotlivých bezpečnostních rizik a protiopatření, která byla zpracována na základě dostupných bezpečnostních pramenů, které se týkaly právě mistrovství Evropy 2012 v Polsku a na Ukrajině. 


\section{BEZPEČNOSTNÍ RIZIKA FOTBALOVÉHO ŠAMPIONÁTU}

Dne 18. dubna 2007 v Cardiffu oznámil předseda Unie evropských fotbalových asociací (UEFA) Michel Platini, že Mistrovství Evropy ve fotbale UEFA EURO 2012 se uskuteční v Polsku a na Ukrajině. Společná kandidatura těchto zemí porazila ostatní uchazečské kandidáty - Itálii a společné pořadatelství Chorvatska a Mad’arska. Šéfové evropského fotbalu se rozhodli dát důvěru Ukrajině s Polskem i přesto, že v průběhu př́pravných prací na kandidaturu panovaly mezi oběma zeměmi neshody a Polsko se navíc také vypořádávalo $\mathrm{s}$ korupcí ve fotbale a s výtržnostmi radikálních fotbalových př́znivců. Ukrajina se zase $\mathrm{v}$ období volby potýkala s nestabilní politickou situací. UEFA jako klíčovou otázku označila zajištění bezpečnosti v průběhu mistrovství. Bezpečnostní koncept předložený uchazečskými zeměmi hodnotil výkonný výbor UEFA velmi pozitivně (Ministry of Interior, 2007a).

Organizace SOS International vydala v květnu 2012 zprávu o bezpečnostních aspektech fotbalového mistrovství Evropy. Celkově bylo Polsko označeno jako středně rizikové, protože bezpečnostní hrozby částečně existovaly. Za největší hrozbu byla považována kriminalita, která byla hodnocena jako středně riziková. Podle zprávy existovalo $\mathrm{v}$ Polsku pouze nízké riziko teroristického útoku, konfliktu, zhoršení politické situace a následných nepokojů, únosů i selhání infrastruktury. Rovněž Ukrajina byla považována jako stř̌edně riziková, protože bezpečnostní hrozby částečně existovaly. Stejně jako v Polsku byla i na Ukrajině označena kriminalita za středně rizikový faktor. Riziko teroristického útoku ohodnotili experti jako nízké, stejně tomu bylo i u ozbrojených konfliktů, přesto bylo zdůrazněno napětí mezi etnickými Rusy a Ukrajinci v regionu. Střední úroveň rizika byla přisouzena politickému napětí a infrastruktuře. Politicky motivované občanské nepokoje byly nebezpečím zejména kvůli sociálním, etnickým a jazykovým rozdílům mezi prozápadně orientovaným západem Ukrajiny a prorusky orientovaným východem země. Naopak podle zprávy existovalo na Ukrajině jen malé riziko únosů (SOS, 2012).

Liedel a Piasecka (2012) identifikovali jako největší ohrožení bezpečnosti turnaje a jeho účastníků terorismus, kriminalitu (včetně organizovaného zločinu), počítačovou kriminalitu, nelegální migraci, chuligánské incidenty a prírodní či technologické katastrofy.

Služba bezpečnosti Ukrajiny uvedla jako největší hrozby v souvislosti s konáním mistrovství Evropy ve fotbale mezinárodní terorismus a organizovaný zločin, použití zbraní hromadného ničení, ilegální migraci a eskalaci mezistátních a občanských konfliktů. V době př́prav na EURO 2012 byla Ukrajina předmětem zvýšeného zájmu mezinárodních zločineckých skupin zejména v oblasti praní špinavých peněz, nelegální migrace a obchodování s lidmi, zbraněmi, nebezpečnými materiály a drogami (SBU, 2011).

Velké obavy panovaly z výtržností fotbalových prŕznivců. V minulosti došlo při střetech polských i ukrajinských chuligánů se soupeři k několika př́ípadům úmrtí. Je známo také spojení neonacistických příznivců s fotbalovým násilím (SOS, 2012).

Lze konstatovat, že obecně byla největší míra rizika $\mathrm{v}$ souvislosti s pořádáním šampionátu přisouzena následujícím třem fenoménům - kriminalitě, možnému teroristickému útoku a chuligánským střetům.

\section{1 Kriminalita}

Zpráva SOS International označila jako zásadní hrozbu kriminalitu, a to především ve formě kapesních krádeží či krádeží nehlídaných věcí, které jsou často hlášeny v centrech velkých měst typu Varšavy či Kyjeva. Ohrožení kriminalitou je zvýšené v okolí veřejných dopravních uzlů, u hlavních turistických památek, na rušných trzích a v blízkosti velkých hotelů, bank a bankomatů.

Návštěvníci Polska a Ukrajiny se podle zprávy měli mít na pozoru před celou řadou známých podvodů. Násilná kriminalita vůči cizincům je podle zprávy SOS International v Polsku i na Ukrajině vzácná, přesto se občas objevuje. Týká se to zejména center měst v nočních hodinách, kdy stoupá riziko fyzického útoku kvůli požití alkoholu či drog. Podle zprávy byl v posledních letech v těchto zemích zaznamenán zvýšený počet incidentů ze strany př́slušníků krajní pravice, neonacistických buněk a skinheads. Násilí je zaměřeno především na rasové a náboženské menšiny a členy homosexuální a transsexuální komunity. Kromě toho zpráva upozornila na popíjení a seznamování se s novými lidmi v zábavních podnicích, zaznamenány totiž byly př́pady zdrogování cizincủ a jejich následné okradení či sexuální zneužití (SOS 2012).

\footnotetext{
${ }^{I}$ Samotný koncept násilí je i na pưdě sportu spojován s filozofii ,, vše je povoleno “. Sociálně a kulturně podmíněný kontext násilí ve sportu pak zahrnuje jeho fyzické, verbální, nonverbální, neetické a symbolické formy a projevy (Sekot, 2008, s. 127).
}

${ }^{2}$ Za únosem a zavražděním izraelských olympioniků stála teroristická organizace Černé záŕí. 


\section{2 Teroristický útok}

Zejména v kontextu událostí z 11. záŕí 2001 získala otázka terorismu mezinárodní rozměry (srov. Tsoukala, 2009). Velké sportovní akce ukázkově ilustrují jak globalizaci sociálních rizik a bezpečnostních hrozeb (což se kromě terorismu týká také výtržnictví a organizovaného zločinu), tak globalizaci bezpečnostních partnerství, norem a dohod (srov. Miller a kol., 2001). Samotné hodnocení teroristických hrozeb závisí na celé řadě místních, národních a nadnárodních faktorů. Problematiku terorismu nemůže řešit jediná akademická disciplína. Př́i zkoumání terorismu nevyhnutelně dochází k tzv. přelévání (spill-overs), kdy je při výzkumu potřeba zkoumat nejen policejní a bezpečnostní strategie, ale také městskou politiku rozvoje, právo, mediální diskurs, sportovní politiku a obecně sociální politiku (Giulianotti \& Klauser, 2010).

Podle předních světových zpravodajských služeb existuje až třikrát větší riziko teroristického útoku v průběhu velké sportovní akce typu olympijských her či mistrovství světa a Evropy ve fotbale než obvykle. Relativně snadný přístup k velkému počtu potenciálních cílů a možnost získat širokou publicitu za spáchané činy zvyšuje nebezpečí teroristického aktu. Situace také může být komplikována širokým spektrem možných způsobů útoku, mezi které patř́i výbuchy, žhářství, zničení technického zázemí či tribun s fanoušky a podobně (SBU, 2011).

EURO 2012 mělo přitáhnout obrovské množství fanoušků, zahraničních funkcionářů a spoustu televizních diváků. Jakýkoli teroristický incident by měl bez ohledu na rozsah nebo trvání dalekosáhlý dopad. V důsledku toho mohlo být fotbalové mistrovství Evropy teoreticky atraktivní pro širokou škálu teroristických skupin a jednotlivců. Konkrétně Polsko je považováno za potenciální terč islámských militantních skupin. Vůdce teroristické organizace Al-Káida Ajmán Zavahrí v minulosti vyzval k útokům mj. na Polsko, a to kvůli zapojení Polska ve vojenských misích v Afghánistánu a Iráku (SOS, 2012).

Před zahájením šampionátu nicméně neexistovaly žádné indicie, které by vedly $\mathrm{k}$ důvodné obavě $\mathrm{z}$ teroristického útoku. Ani v jedné z hostitelských zemí nebyly podle informací prrítomny žádné domácí nebo mezinárodní teroristické organizace, v Polsku ani na Ukrajině navíc nežije početně významná muslimská populace, která by potenciálně mohla podporovat islamistické elementy. Ačkoli měly polské a ukrajinské bezpečnostní a zpravodajské služby malé zkušenosti v boji proti terorismu, opatření před teroristickým útokem byla považována za uspokojující (SOS, 2012).

27. dubna 2012 explodovaly při bombovém útoku v centru Dněpropetrovsku čtyři nálože, pátou se podařilo pyrotechnikům zneškodnit. Zranění utrpělo jednatřicet lidí včetně deseti dětí, šestadvacet osob bylo hospitalizováno. Motivy útoků zůstávaly zprvu neznámé. Prokuratura výbuchy vyšetřovala jako teroristický čin. Podle ukrajinských médií za nimi spíše než teroristé stály gangy soupeřící o vliv nad městem. Objevila se ale i teorie, že šlo o snahu ukrajinských úřadů odvést pozornost od dalšího procesu s vězněnou expremiérkou Julijí Tymošenkovou (ČTK, 2012).

Ukrajinské bezpečnostní složky obvinily z výbuchů čtyři ukrajinské občany. Služba bezpečnosti Ukrajiny v ř́jnu 2012 uvedla, že podezřelí se snažili zmařit konání fotbalového mistrovství Evropy na Ukrajině. Pachatelé prý nesouhlasili se společenským a politickým režimem. Chtěli způsobit chaos a vyvolat protesty veřejnosti proti státním orgánům. Bezpečnostní složka Ukrajiny také podezř́ivala dva z obviněných z přípravy dalších tří výbuchů v Charkově, Záporoží a Dněpropetrovsku v roce 2011 (Interfax, 2012).

I v souvislosti $\mathrm{s}$ bombovým útokem se $\mathrm{v}$ německých médiích hovořilo o tom, že Německo bylo podle policejních odborů připraveno od Ukrajiny na poslední chvíli převzít pořadatelství. Představitelé UEFA to však kategoricky odmítli a uvedli, že by to ani v tak krátkém čase nešlo provést (ČTK, 2012a).

\subsection{Chuligánské střety a výtržnictví}

Izolované případy do očí bijícího davového násilí sportovních fanoušků jsou dnes spíše výjimkou. Pokud k němu však dochází, čelíme zpravidla vážným projevům sociálních deviací. V tomto ohledu se aktualizují i možné limity systematického úsilí organizátorů sportovních akcí a policie předcházet negativním jevům na půdě sportu (Sekot, 2008, s. 126).

Ukazuje se, že jen marginální část divácké obce jde na stadiony s cílem vyvolávat konflikty. Ty pak jsou spíše výsledkem situačních podnětů, chybějící prevence a selhání kontrolních mechanismů majících zabránit vzniku takovýchto reakcí prímo v hledištích (Slepička a kol., 2010, s. 49; Mikšík, 2005, s. 185; Frosdick, \& Marsh, 2005, s. 25-26; Kasal, 2013, s. 7).

Současná realita sportovního diváctví přirozeně stále častěji a naléhavěji upozorňuje na fenomén moderního fotbalového chuligánství. Vzhledem k jeho společenské závažnosti si připomeneme, že pod projevy fotbalového 
chuligánství sociologie a psychologie vřazují takové projevy jako vniknutí na hrací plochu ${ }^{3}$, házení předmětů na hrací plochu, výtržnosti, vandalismus, verbální i neverbální konflikty mezi chuligány a rozhodčím či pořadateli a fotbalovými chuligány navzájem (blíže viz Giulianotti, 1999; Slepička, 1990; Smolík, 2002; Sekot 2006). V postkomunistické části Evropy, do které Polsko i Ukrajina patríí, lze projevy diváckého násilí vyvolané skupinami fotbalových chuligánů vysledovat ve větší míŕe v průběhu devadesátých let 20. století (Mareš, Smolík, \& Suchánek, 2004). Tilly (2006) konstatuje, že fotbalové násilí se nepochybně stalo mezinárodním jevem. Lze však konstatovat, že pro některé země jsou tyto násilné rituály typické a charakteristické (viz Tilly, 2006, s. 88). Často je chuligánství vnímáno i jako tzv. fotbalový fanatismus ${ }^{4}$.

Chuligánství je založeno na partách (tlupách) většinou mladých „příznivců“, kteří přicházejí na fotbalové stadiony s primárním cílem vyvolat konflikt či bitku s jinými podobnými skupinami soupeřova týmu. Tyto skupiny (party, tlupy) mají vlastní názvy, kterými se vymezují od neorganizovaných skupin i vůči jiným skupinám. Některé z těchto part jsou velice dobře organizovány a nesjednocuje je jenom klubové rivalství a nenávist k nepřátelským chuligánským skupinám, ale i politické, rasové, náboženské, národnostní, regionální a sociální motivy (srov. Taylor, 1971; Dunning, Murphy \& Williams, 1988; Giulianotti, 1999; Smolík, 2010).

V současnosti je fotbalová chuligánská scéna natolik etablovaná ve společnostech téměř všech evropských států, že nelze mluvit o jednotlivých skupinách, které jsou navzájem izolované a separované. Tyto skupiny dnes tvoří sít' bilaterálních i multilaterálních dohod a přátelství (družby), které mají často přeshraniční přesah (viz Kasal, 2013, s. 28).

Fenomén tzv. diváckého násilí se sice dotýká obou pořadatelských zemí, mnohem značněji je však rozšířen v Polsku, proto se tato část zaměří zejména na Polsko. Hlavní důvodem velké rozšířenosti tohoto fenoménu je fakt, že organizované skupiny fotbalových chuligánů nejsou v Polsku záležitostí pouze velkých a populárních klubů, ale utváří se i u málo známých celků z menších měst, které působí v nižších soutěžích. Pravděpodobnost násilných střetů mezi nejrůznějšími chuligánskými gangy je tak značně vysoká (Mareš, Smolík, \& Suchánek, 2004; Smolík, 2008).

Nejen v Polsku se na ustawki ${ }^{5}$ pohlíží jako na protiprávní jednání. Konkrétně v Polsku se využívá k obvinění paragraf 158 trestního zákona - „,bójky“ (tedy „boje“), což je speciální paragraf, který se uplatňuje při rvačce tř́ a více osob ${ }^{6}$. Obviněna může být nejen osoba, která se aktivně účastní rvačky, ale i osoba, která se aktivně nezapojila, ale třeba jen stojí bokem a ostatní povzbuzuje. Trest je až tři roky vězení (KKP, nedat.).

Polští fotbaloví chuligáni jsou již od 90. let považováni za nejproblematičtější v Evropě. Při jejich střetech není neobvyklé používání nožů, železných tyčí nebo dokonce zápalných lahví, což má často závažné následky (v posledních letech i ztráty na lidských životech). Policie je v Polsku na rizikových fotbalových utkáních vyzbrojena puškami na gumové projektily, které v prŕípadě násilností neváhá použít ${ }^{7}$ (Smolík, 2008, s. 33).

Při zápasech polské fotbalové reprezentace není udržován vzájemný smír mezi jednotlivými chuligánskými skupinami. Polští chuligáni tak berou utkání svého národního celku pouze jako další příležitost pro vyvolání násilných incidentů (Mareš, Smolík, \& Suchánek 2004).

Na reprezentační úrovni se významné střety vyskytly v minulosti např́iklad při MS v Německu v roce 2006, kdy se polští př́iznivci střetli s německými radikály během vzájemného zápasu hraného v Dortmundu 14. 6. 2006 (viz Smolík, 2008).

I proto začala polská policie před fotbalovým mistrovstvím Evropy 2012 chuligánské střety bedlivě sledovat a trend pokračoval i po šampionátu, kdy policisté rozbili nejlepší polské „ustawkové“ ekipy. Zátahy a zatýkání se týkaly nejen nejsilnějších táborů (Lechu Poznaň, Ruchu Chorzów, Widzewu Lodž či Lublinu), ale i dalších skupin. Známé české webové stránky www.hooligans.cz, které mapují dění na české i zahraniční chuligánské scéně, v jednom ze svých článků z konce března 2013 poukazují na fakt, že v Polsku je doba na ustawky velmi nepř́znivá (hooligans, 2013).

\footnotetext{
3 Z hlediska závažnosti diváckých reakci patři právě vhazování předmětů na hrací plochu $k$ těm negativním projeviom s největším dopadem na probihajici sportovni utkání. Jde o situace, jež ohrožuji aktéry utkání, navozují negativní atmosféru v hledišti a vytvárejí předpoklady pro uplatněni mechanismu nápodoby. (Slepička a kol., 2010, s. 70).

${ }^{4}$ Fanatismus lze definovat jako nadměrné a nekritické nadšení bez rozumové kontroly, oddanost určité viřre, vyvolávajicí silné citové postoje, horlivou činnost, ale i nesnášenlivost.

5 Ustawka (také grillowanie) je boj na predem určeném místě a za ustálených podmínek. Jedná se o střetnutí dvou chuligánských skupin nejlépe daleko od stadionu a od ostatnich lidí. Existuji dva typy ustawek; bud' jde o boj 5 proti 5 , 20 proti 20 či třeba 50 proti 50, nebo se střetne tzv. banda na bandu, tedy bez početního limitu osob (Kowalska, 2007).

${ }^{6}$ Účast na násilných akcích je pro tyto osoby zdrojem uznání a prestiže. Vyvolávání bitek a úspěch v nich je též dưležitou součástí kolektivní prestiže jednotlivých chuligánských skupin. K faktorům, které se podíleji na tomto druhu agrese, je přrirazován napřiklad alkohol, anonymita, specifické prostředi atp. (srov. Taylor, 1971; Lovaš, 2010; Slepička a kol., 2010; Kasal, 2013).

${ }^{7}$ V květnu 2004 došlo ke dvěma úmrtím poté, když polská policie omylem použila ostré náboje při násilnostech mezi fotbalovými chuligány a studenty slavícimi majáles v Lodži (Smolik 2008, s. 33-34).
} 


\section{OPATŘENÍ VEDOUCÍ K ZAJIŠTĚNÍ BEZPEČNOSTI ŠAMPIONÁTU}

Od měst a národů, které usilují o pořádání velké sportovní události, se v prvé řadě očekává, že vytvoří takové prostředí, ve kterém se návštěvníci i sportovci nebudou obávat bezpečnostních hrozeb. Mohou být přijaty nové právní předpisy poskytující bezpečnostním složkám větší pravomoci při ochraně veřejných prostranství, zároveň však tyto př́edpisy mohou ohrozit určité formy občanské svobody, jako je např. právo na politický protest nebo veřejné shromažd'ování (Giulianotti \& Klauser, 2012).

\subsection{Polsko}

$\mathrm{Na}$ tiskové konferenci s polskými ministry vnitra, spravedlnosti a sportu dne 19. dubna 2007 byla prezentována očekávaná nebezpečí vyplývající z obrovského rozsahu této sportovní události (k roli médií viz Děkanovský, 2008). Bylo naplánováno osm nových hraničních přechodů mezi Polskem a Ukrajinou. Již tehdy se hovořilo o možnosti provádět kontroly na vnitřních hranicích Evropské unie, ačkoli Polsko očekávalo vstup do Schengenského prostoru. Polské ministerstvo vnitra pracovalo v souvislosti s mistrovstvím na tísňovém telefonním čísle 112, které mělo být do zahájení šampionátu k dispozici v různých jazykových verzích. V plánu byla mj. novelizace trestního zákoníku, která měla klasifikovat nové trestné činy spáchané na stadionu a zpř́snit některé přečiny (Ministry of Interior, 2007b).

Za bezpečnostní př́pravy na finálový turnaj EURO 2012 bylo zodpovědné ministerstvo vnitra, dále národní koordinátor ze společnosti PL.2012, bezpečnostní koordinátoři v jednotlivých hostitelských městech a bezpečnostní manažer ze společnosti POLAND EURO 2012. Otázky týkající se bezpečnosti šampionátu byly v největší míře v kompetenci těchto státních institucí:

1) Ministerstvo vnitra, jež bylo také zodpovědné za koordinaci prací všech ostatních ministerstev a ústředních orgánů, které byly zapojeny do př́pravy turnaje;

2) Agentura vnitřní bezpečnosti, která měla na starosti prevenci teroristických hrozeb;

3) Ministerstvo obrany, které bylo zodpovědné za bezpečnost mořských hranic a vzdušného prostoru;

4) Vojenská policie, která poskytovala podporu státní policii;

5) Vládní bezpečnostní centrum, což je národní centrum pro krizový management (Liedel \& Piasecka, 2012).

Polský premiér Donald Tusk v záŕí 2008 jmenoval Bezpečnostní radu pro sportovní události, mezi jejíž úkoly patřila koordinace projektů zaměřených na prevenci násilí a kladení důrazu na meziinstitucionální př́stup k bezpečnosti. Tento poradní orgán premiéra rovněž spolupracoval se Stálým výborem Rady Evropy pro bezpečnost sportovních akcí (Liedel \& Piasecka, 2012).

V květnu 2010 zrrídil polský ministerský předseda Výbor pro ochranu a bezpečnost při EURO 2012. Hlavním úkolem výboru bylo koordinovat opatření přijatá všemi orgány a službami, které byly zapojeny do bezpečnostních operací týkajících se fotbalového mistrovství Evropy. Výbor pro ochranu a bezpečnost vyvinul Integrovaný koncept bezpečnosti, jenž měl tvořit základ činností důležitých k zabezpečení turnaje v Polsku (Ministry of Interior 2011).

Polská policie pracovala před šampionátem s filozofií známou jako tzv. „3×T“ - Troska, Tolerancja, Tłumienie, což v překladu znamená péče, tolerance a tlumení/potlačení. Policie měla během šampionátu na starosti řadu specifických úkolů, např. hledání případných výbušných zařízení na stadionech či na vozidlech, která měla přístup na stadion, dále měla zajistit př́itomnost spotterů ${ }^{8}$, ,přátelsky“ uniformovaných policistů na stadionech a v okolí stadionu, integrovanou spolupráci s bezpečnostními a informačními službami a také přítomnost pořádkových jednotek v bezprostřední blízkosti stadionu (Liedel \& Piasecka, 2012). Do popředí se také dostávala otázka bezpečnosti na polských fotbalových stadionech, jelikož vhodně vybavené stadiony eliminují případné násilné excesy nejenom uvnitř sportovišt', ale i v jejich nejbližším okolí (srov. Leška, 2004, s. 155).

Pro potřeby šampionátu zřídilo polské ministerstvo vnitra policejní operační centrum ve městě Legionovo. Toto místo mělo sloužit pro koordinaci policejních činností v průběhu fotbalového mistrovství. Kromě polských policistů zde pracovali zástupci Europolu, Interpolu a IMEST, což je podpůrná skupina Interpolu pro masové akce. Působily zde i policejní posily z Řecka, Ruska, České republiky, Španělska, Itálie, Irska, Chorvatska, Anglie, Nizozemska, Dánska, Německa, Portugalska, Švédska, Slovinska, Mad’arska, Rakouska, Slovenska

8 Spotteři (pozorovatelé z hostujici země) jsou policisté v civilu, kteři pomáhaji policejním orgánům hostitelské země identifikovat př́padné výtržníky a upozorňují na zárodky bližicího se střetu (Bureš, 2005; Kasal, 2013). 
a Ukrajiny. Součástí policejního operačního centra byli také zástupci pohraniční stráže, hasičů, Agentury vnitřní bezpečnosti, železniční policie, ministerstva obrany a ministerstva dopravy, výstavby a námořního hospodářství (Ministry of Interior 2012a).

Policejní operační centrum spolupracovalo s policejním ředitelstvím ve Varšavě a s vojvodskými ředitelstvími policie v hostitelských městech, tedy ve Vratislavi, Poznani a Gdaňsku. Rovněž koordinovalo dílčí operace v Krakově, Lublinu a Řešově, což jsou města, přes která fanoušci projížděli při cestě k zápasům hraným na Ukrajině. Kromě policejního operačního centra Polsko v souvislosti s pořádáním mistrovství Evropy ve fotbale mj. přestavělo městské policejní ředitelství v Poznani, modernizovalo vozový park a investovalo do moderních ochranných oděvů pro policisty (tamtéž).

Důležitým prvkem při práci na zajištění bezpečnosti EURO 2012 byla revize polského zákona o bezpečnosti masových akcí. Úprava zákona, která vstoupila v platnost 12. listopadu 2011, obsahovala ustanovení o zvláštních pravomocech policie ve vztahu k turnaji a také další předpisy, které se týkaly jiných veřejných bezpečnostních služeb, jako je např. pohraniční stráž či požární služba. Novela obsahuje ustanovení, podle něhož může soud nařídit konkrétním osobám, že po dobu konání masové akce musí zůstat v místě svého bydliště. Ve zvláštních př́padech může soud rozhodnout také o povinnosti odsouzené osoby hlásit se na určité policejní stanici i po skončení trestu (Liedel \& Piasecka 2012).

Dne 13. ledna 2012 vstoupila v Polsku v platnost nová legislativní opatření, která pozměnila zákon o zabezpečení hromadných událostí a několik dalších zákonů. Díky tomu mohou být uloženy př́snější sankce osobám, které představují hrozbu pro bezpečnost masových událostí a kterým může být snadněji udělen zákaz vstupu na stadion. Byl zaveden monitoring chuligánů s elektronickými náramky, zároveň mělo být udíleny př́snější tresty za falešné anonymní zprávy o bombách. Polští poslanci také provedli změnu, podle které je možné vykonávat soudní řízení přímo na stadionu, slyšení mělo být prováděno prostřednictvím videokonference. Hlavním cílem nové legislativy bylo vytvoření účinných prostředků pro boj proti výtržnictví a v důsledku tedy zajištění bezpečnosti v průběhu mistrovství Evropy (Ministry of Interior, 2012b).

Rozhodnutím polského ministra vnitra se dočasně (od 4. června do 1. července 2012) znovu zavedly hraniční kontroly na vnitřních hranicích schengenského prostoru, což byl jeden z činů důležitých pro zvýšení úrovně bezpečnosti při mistrovství Evropy ${ }^{9}$.

O bezpečnost fotbalového mistrovství Evropy 2012 se v Polsku starala i armáda. Vojáky mělo na starost velitelství, které je zodpovědné za operace v Afghánistánu a na Balkáně. Polští vojáci byli připraveni během EURO 2012 zakročit v př́ípadě, že by běžné bezpečnostní síly, převážně policie, na situaci nestačily. Jednalo by se např́klad o př́ípad teroristického útoku. V každém ze čtyř měst, kde se šampionát hrál, působilo jedno úkolové uskupení polské armády. V něm se nacházely jednotky starající se o průzkum, biologické nebezpečí či například odminování. Mezi vojáky, kteří se starali o bezpečnost během turnaje, měla být i polská komanda, která mají zkušenosti s protiteroristickými operacemi v Afghánistánu. Ochranu šampionátu měly posílit i vojenské zpravodajské složky. Výrazným způsobem mělo dojít k posílení protiletecké obrany. Na EURO měly dohlížet další dvě stíhačky F-16 nebo speciální alianční letoun systému AWACS, který může sledovat cíle ve vzduchu anebo odposlouchávat nepřátelské stroje. Malá letadla, vrtulníky anebo motorové padáky nad turnajová města a Krakov nesměly, musely být od nich minimálně 50 kilometrů. Přelety nebyly dovoleny ani nad zónami pro fanoušky (Gazeta Wyborcza, 2012).

\section{2. Ukrajina}

Na Ukrajině existovaly tři hlavní státní struktury, které se staraly o prrípravné práce na finálový turnaj fotbalového mistrovství Evropy EURO 2012:

1) Výbor pro př́pravu a pořádání finálového turnaje mistrovství Evropy ve fotbale 2012 na Ukrajině poradní orgán prezidenta Ukrajiny.

2) Národní agentura pro př́pravu a pořádání finálového turnaje mistrovství Evropy ve fotbale 2012 na Ukrajině a realizaci infrastrukturních projektů - v gesci ukrajinské vlády.

3) Mezirezortní koordinační tým zaměřený na bezpečnost (Soloviov, 2012).

Mezirezortní koordinační tým zaměřený na bezpečnost vznikl 10. prosince 2010 a měl koordinovat aktivity orgánů činných v trestním řízení a místních vládních organizací důležité $\mathrm{k}$ zajištění bezpečnosti při přípravě a pořádání finálového turnaje mistrovství Evropy. Mezi členy týmu byli př́islušní zástupci ústřední výkonné

\footnotetext{
9 Toto opatření dovolovalo nevpustit osoby považované za hrozbu pro bezpečnost a veřejný poŕádek na polské území, což
} mělo prispět $k$ zvýšení bezpečnosti (Ministry of Interior, 2012c). 
moci a úr̆adů a hlavou týmu byl první místopředseda Národní agentury pro př́pravu a pořádání finálového turnaje mistrovství Evropy ve fotbale 2012 na Ukrajině Alexander Birsan. Tento koordinační tým pracoval na řadě protiteroristických opatření a na schůzi štábu v červenci 2011 byla za účasti ukrajinského prezidenta diskutována problematika fan zón, rozdělení funkcí a pravomocí bezpečnostních subjektů a otázka zdravotního zabezpečení. Alexander Birsan informoval o revizi Koncepce zabezpečení EURO 2012 a o vypracování souhrnného akčního plánu bezpečnosti v průběhu organizace turnaje (Soloviov, 2012).

Hlavním endogenním faktorem, který negativně ovlivňoval přípravu a pořádaní mistrovství Evropy, bylo posílení různých geopolitických vlivů, které destabilizovaly bezpečnostní prostředí a ohrožovaly národní bezpečnost Ukrajiny. Na začátku roku 2011 došlo na Ukrajině k některým trestným činům, které s vysokou pravděpodobností naznačovaly zintenzivnění subverzivních postojů ve společnosti a projevy pravicového extremismu a terorismu (SBU, 2011).

Podle požadavků UEFA odpovídala za bezpečnost na mistrovství Evropy ukrajinská vláda. Na přípravě a organizaci EURO 2012 se podílelo také pět ministerstev - ministerstvo zahraničních věcí, vnitra, obrany, zdravotnictví a krizových situací a také pohraniční stráž a Služba bezpečnosti Ukrajiny. Za účelem optimalizace mezinárodní spolupráce a koordinace bezpečnostních opatření v průběhu šampionátu bylo na zasedání Národní bezpečnostní a obranné rady Ukrajiny dne 17. listopadu 2010 rozhodnuto o založení mezinárodní agentury, která se měla věnovat právě koordinaci bezpečnostních opatření. Dne 10. března 2011 tak vznikl Tým pro mezinárodní spolupráci a koordinaci bezpečnostních opatření při př́pravě a pořádání finálového turnaje mistrovství Evropy 2012 jako pomocný orgán prezidenta Ukrajiny. Hlavní součástí tohoto týmu bylo protiteroristické centrum Služby bezpečnosti Ukrajiny (Soloviov, 2012). Službě bezpečnosti Ukrajiny pomáhala při protiteroristických př́ípravách na EURO 2012 také americká FBI (Interfax, 2010).

Pro potřeby šampionátu bylo v Kyjevě zřízeno Centrum policejní spolupráce, jež úzce spolupracovalo se zahraničními policisty, kteří na Ukrajině doprovázeli př́znivce ze svých zemí (ICU, 2012a).

Mezi hlavní právní akty, které upravovaly otázky bezpečnosti při EURO 2012, patřil v první řadě Integrovaný koncept bezpečnosti při př́pravě a pořádání finálového turnaje mistrovství Evropy 2012, který byl v souladu s doporučeními evropské fotbalové unie UEFA schválen kabinetem ministrů v listopadu 2009. Dne 14. dubna 2010 schválil kabinet ministrů Ukrajiny Státní program pro př́pravu a pořádání finálového turnaje mistrovství Evropy 2012, který nastínil úkoly důležité k zajištění veřejného pořádku a osobní bezpečnosti, $\mathrm{k}$ boji proti terorismu a vyjádřil potřebu vytváření moderních systémů podstatných při krizových situacích (Soloviov, 2012).

\section{3. Mezinárodní spolupráce}

Spolupráce Ukrajiny s Polskem v oblasti bezpečnosti existovala na základě Prohlášení o spolupráci v otázce zabezpečení EURO 2012, které vzniklo v rámci Ukrajinsko-polského výboru pro přípravu a pořádání EURO 2012 a př́íslušných mezivládních pracovních skupin, v nichž se nacházeli zástupci vládních struktur. Služba bezpečnosti Ukrajiny a polská Agentura vnitřní bezpečnosti podepsaly v záŕí 2009 dvoustranné dohody o spolupráci. V rámci těchto dohod byla vyvinuta spolupráce $\mathrm{v}$ boji proti terorismu, byly vytvořeny plány pro společné preventivní protiteroristické cvičení a zároveň si tyto bezpečnostní složky vyměnily př́slušné informace. Velvyslanectví Polska na Ukrajině mělo svého styčného důstojníka, který byl zástupcem ministerstva vnitra. Podobná pozice byla vytvořena na ukrajinské ambasádě v Polsku, kde tento post zastával zástupce Služby bezpečnosti Ukrajiny (Soloviov, 2012).

Ukrajina a Polsko spolupracovaly na vytvoření systému rychlého potrestání fotbalových chuligánů při EURO 2012. V roce 2010 v Istanbulu se na konferenci Rady Evropy shodli ministři spravedlnosti Ukrajiny a Polska na obsahu tří dohod, které byly podepsány v Polsku na začátku roku 2011. Jedná se o Memorandum o spolupráci mezi oběma ministerstvy, dále o Dohodu o právní pomoci ve věcech občanských a trestních a o Dohodu o užívání dvojjazyčných žádostí o právní pomoc v občanských případech. Spolupráce mezi Ukrajinou a Polskem probíhala $\mathrm{v}$ několika rovinách. Ukrajinští odborníci se zúčastnili semináře NATO o ochraně proti zbraním hromadného ničení v průběhu velkých veřejných akcí, který se konal v lednu 2011 v Polsku. Zvláštní pozornost byla věnována protiteroristickým bezpečnostním aspektům EURO 2012 (Soloviov, 2012).

Mezinárodní spolupráce Polska s ostatními zeměmi byla realizována na základě společného prohlášení (Memorandum of Understanding) o spolupráci v oblasti bezpečnosti v souvislosti finálovým turnajem mistrovství Evropy ve fotbale UEFA EURO 2012. Toto prohlášení podepsal nejvyšší velitel polské policie a oprávnění zástupci policií dalších zemí. Svůj podpis přidaly tyto země - Ukrajina, Rusko, Itálie, Řecko, Chorvatsko, Dánsko, Česká republika, Německo, Slovensko, Rakousko, Portugalsko, Španělsko, Anglie, 
Holandsko a Švédsko. S policií z Irska a Francie bylo spolupracováno na základě výzvy o spolupráci, tzv. „Protocol for Deployment“, která byla podepsána nejvyšším velitelem polské policie a následně poslána zúčastněným stranám. V průběhu turnaje polská policie spolupracovala se 174 policisty z 15 zemí, mezi nimiž byli také pracovníci INTERPOLU a EUROPOLU. Nejvíce zahraničních př́slušníků policie, tzv. spotterů, bylo z Chorvatska, a to šestnáct. Z Německa do Polska vyrazilo dvanáct spotterů, z Ruska, Itálie a Španělska shodně po deseti. Ve Varšavě a Gdaňsku vypomáhalo také osm portugalských a šestnáct německých policistů (PRP, 2012).

\section{4 Činnost Policie České republiky v souvislosti se šampionátem}

Vzhledem k místu konání šampionátu a účasti českého reprezentačního týmu předpokládala Policie ČR vysokou účast Čechů na zápasech základní skupiny. Česká republika sehrála všechny tři zápasy základní skupiny (8., 12. a 16. června 2012) na městském stadionu v polské Vratislavi. Celé opatření v souvislosti s konáním mistrovství bylo v gesci Policejního prezidia ČR. Pro zajištění hladkého průběhu šampionátu byli vyčleněni policisté ze všech služeb, zejména tedy pořádkové, dopravní, kriminální i cizinecké. Kromě zajištění veřejného pořádku pracovali čeští policisté ve společných hlídkách se zahraničními kolegy při kontrolách na hranicích. Po celou dobu šampionátu a zejména při utkáních českého týmu posílili dopravní policisté hlídky v př́hraniční oblasti s Polskem a dohlíželi na provoz na silnicích. Současně byl nasazen i policejní vrtulník, který monitoroval situaci v několika krajích České republiky (PČR, 2012a).

Dne 4. června odjeli do Polska první policisté služby kriminální policie a vyšetřování. Jednalo se o 12 spotterů, kteří se (ve spolupráci s kolegy $\mathrm{z}$ dalších zúčastněných zemí) prŕímo na stadionech soustředili na identifikaci skupin rizikových fanoušků či jednotlivcủ ${ }^{10}$. Do Polska a na Ukrajinu odcestovali i dva styční důstojníci, jejichž úkolem bylo zajištění komunikace mezi jednotlivými policejními složkami př́mo na místě (PČR, 2012b).

Do polské Vratislavi odjelo 7. června 2012 padesát policistů pořádkové policie. Od 8. června se zapojili do činnosti dalších bezpečnostních složek v místě konání zápasu našeho národního týmu (PČR, 2012c). Bylo mezi nimi také dvanáct policistů $\mathrm{z}$ antikonfliktního týmu, kteří se rovněž v průběhu šampionátu úspěšně podíleli na bezpečnostních opatřeních souvisejících s mistrovstvím (PČR, 2012d).

Vzhledem k tomu, že prevence tzv. diváckého násilí se týká i sociální práce, lze jako podpůrnou vnímat i činnost tzv. fanouškovské ambasády, která ČR osvědčila i v př́ípadech předchozích šampionátů (viz Jusko 2009; Jindrová \& Smolík, 2009).

\section{PRŮBĚH ŠAMPIONÁTU Z HLEDISKA BEZPEČNOSTI}

Finálový turnaj fotbalového mistrovství Evropy ve fotbale UEFA EURO 2012 se v Polsku a na Ukrajině uskutečnil v období od 8. června 2012 do 1. července 2012. Šestnáct národních fotbalových mužstev odehrálo dohromady jednatřicet zápasů na osmi stadionech.

\section{1. Polsko}

Polská policie nazvala největší akci své moderní historie symbolicky - Hattrick 2012. Hlavním úkolem této policejní operace byla ochrana života a zdraví lidí a majetku před protizákonnými útoky a také ochrana veřejného pořádku, včetně zajištění bezpečnosti na veřejných místech po celém Polsku a na trasách, po kterých se pohybovali účastníci turnaje. V Polsku se odehrálo patnáct zápasů ve čtyřech městech - dvanáct utkání základní části, dva čtvrtfinálové zápasy a jedno semifinálové klání. Přímo na polských stadionech sledovalo zápasy přes 600 tisíc lidí. V zónách pro fanoušky se objevilo přes 2,5 milionu fanoušků, což je více než dvojnásobek ve srovnání s počtem fanoušků, kteří zavítali do fan zón v Rakousku při minulém mistrovství Evropy ve fotbale, které se konalo v roce 2008 (PRP 2012a).

Na bezpečnost dohlíželo v den zápasu mezi Polskem a Ruskem 6379 policistů, o čtyři dny později bylo v den utkání Ruska s Řeckem ve Varšavě 7408 policistů. V úvodní fázi turnaje byly hlášeny tři vážné incidenty. Kromě útoku na pořadatele, který se odehrál 8. června 2012 ve Vratislavi, se jednalo zejména o střet polských a ruských příznivců dne 12. června ve Varšavě. Tuto událost lze s odstupem času považovat za vůbec největší

10 Tuto činnost vykonávají v zahraniči pravidelně od fotbalového mistrovství Evropy v Portugalsku v roce 2004 (PČR, 2012b). 
narušení bezpečnosti v průběhu konání fotbalového mistrovství Evropy v Polsku a na Ukrajině (Ministry of Interior, 2012d). V den utkání Polska s Ruskem policie dohromady zadržela 192 výtržníků, z tohoto počtu bylo 164 Poláků a 28 cizinců (PRP, 2012a).

Jako třetí vážnější incident $\mathrm{v}$ průběhu skupinové fáze šampionátu označila polská policie událost z 16 . června 2012, kdy před utkáním Ruska proti Řecku ve Varšavě házeli výtržníci lahve na policisty (Ministry of Interior, 2012d). 27. června 2012 nařídil polský premiér zvýšit stupeň ohrožení vzhledem k možné teroristické hrozbě, čímž se navýšila ostražitost všech bezpečnostních sil a úředníků veřejné správy v zemi (Ministry of Interior, 2012e).

Kromě dvanácti zápasů základních skupin se v Polsku odehrály tři zápasy vyřazovací části - dvě čtvrtfinálová utkání a jedno semifinále. V průběhu této nadstavbové části polská policie nezaznamenala vážnější incidenty, které by narušily bezpečnost šampionátu.

V průběhu turnaje policie zatkla 652 lidí, z toho 473 Poláků a 179 cizinců, mezi nimiž bylo sto Rusů, jednadvacet Chorvatů a devatenáct Irů. Často docházelo k zadržení zejména v souvislosti s narušením veřejného pořádku. Celkem 110 osob se provinilo nepovoleným shromažd’ováním, 113 lidí porušilo zákon o bezpečnosti masových akcí, 70 osob bylo zadrženo kvưli útoku na veřejného činitele a 49 lidí se provinilo zapojením do boje nebo napadením. Třiadvacet osob bylo dočasně zadrženo, z toho čtrnáct Poláků, sedm Rusů, jeden Mad’ar a jeden Chorvat. Soud jim v urychleném rrízení udělil různé tresty - odnětí svobody od tří měsíců do jednoho roku s podmíněným odkladem výkonu trestu na čtyři roky, dále zákaz přístupu na veřejné akce po dobu pěti let, pokuty od 500 do 4000 polských zlotých a nařídil i 50 hodin veřejně prospěšných prací (PRP, 2012a).

Téměř 1200 př́slušníků vojenské policie poskytlo v průběhu šampionátu přímou podporu policii a pohraniční stráži. Mezi hlavní úkoly polské vojenské policie náležela ochrana veřejného pořádku ve městech, které hostily turnajové zápasy, a to především v okolí stadionů, v místech s vysokou koncentrací fanoušků a v místech, kde pobývaly fotbalové reprezentace. Celkem se v Polsku ubytovalo třináct z šestnácti reprezentačních výprav. Vojáci plnili službu rovněž v místech, z nichž byli někteří policisté přeloženi do hostitelských měst. Vzhledem k zvýšenému provozu na cestách se prŕslušníci vojenské policie zaměřili také na bezpečnost na cestách (ŻV 2012).

Polská policie doprovázela při přejezdech fotbalové týmy, rozhodčí, pozorovatele UEFA a další osoby. Policisté měli k dispozici sedmnáct vrtulníků a dopravních letounů CASA. Tyto stroje transportovaly z Polska na Ukrajinu skupiny španělských, portugalských a italských policistů. V průběhu turnaje byla úroveň bezpečnosti v pořadatelských městech a Krakově, tedy v městech, které hostily fotbalové týmy a mnoho fanoušků, na vysoké úrovni. Statistiky vykazují méně zločinů a přestupků ve srovnání se stejným obdobím roku 2011 (PRP 2012a).

V průběhu fotbalového mistrovství Evropy překročily hranice Polska přibližně dva miliony lidí ${ }^{11}$. Největší nárůst objemu dopravy byl zaznamenán zejména díky chorvatským a irským fanouškům na letištích v Poznani a Gdaňsku. Na všech hranicích bylo dohromady zadrženo čtrnáct cizinců, dalším dvaadvaceti nebyl umožněn vstup do Polska (Ministry of Interior, 2012e).

\section{2 Ukrajina}

$\mathrm{Na}$ Ukrajině se odehrálo celkem dvanáct zápasů základních skupin. V každém ze čtyř hostitelských měst Lvov, Charkov, Doněck a Kyjev - se odehrály ve skupinové fázi turnaje tři utkání. V Doněcku se uskutečnilo ještě čtvrtfinále a semifinále, Kyjev hostil čtvrtfinálový zápas a také finálové utkání. Za obzvláště rizikové označila zpráva SOS International zápasy základní skupiny mezi Ukrajinou a Anglií a dále mezi Nizozemskem a Německem (SOS, 2012).

Ukrajinské bezpečnostní složky na rozdíl od polské části turnaje nezaznamenaly žádné vážné incidenty, které by narušily bezpečnost $\mathrm{v}$ průběhu turnaje. Např́klad na bezpečnost $\mathrm{v}$ den finálového zápasu mezi Španělskem a Itálií dohlíželo v Kyjevě více než sedm tisíc policistů a strážníků (Obozrevatel, 2012). V den čtvrtfinálového zápasu mezi Anglií a Itálii zajišt’ovalo v Kyjevě bezpečnost 3564 policistů a 1627 strážníků (ICU, 2012b). Na veřejný pořádek pak v průběhu semifinálového zápasu v Doněcku mezi Portugalskem a Španělskem dohlíželo 3558 policistů a 148 strážníků (ICU, 2012c).

Celkem dvaadvacet tisíc ochránců zákona zajištovalo bezpečnost v hostitelských městech na Ukrajině v hracích dnech, v ostatních dnech jejich počet klesl na jedenáct tisíc (ICU 2012d).

11 Ve srovnáni s časově stejně dlouhým obdobím před šampionátem to představuje nárůst o deset procent (Ministry of Interior, 2012e). 
V průběhu fotbalového mistrovství Evropy navštívilo Kyjev téměř třiašedesát tisíc zahraničních fanoušků; nejvíce (sedmnáct tisíc) jich přijelo ze Švédska, ze Španělska dorazilo osm tisíc prríznivců, z Ruska a Anglie shodně po šesti tisících. Finálový zápas v Kyjevě sledovalo celkem osmnáct hlav zahraničních států. Žádné závažné trestné činy v hlavním městě v souvislosti s konáním šampionátu ukrajinské bezpečnostní složky neevidovaly (ICU, 2012e).

V průběhu šampionátu nebyly na Ukrajině ani v Polsku hlášeny žádné incidenty týkající se rasismu, ačkoli právě z projevů rasismu panovaly před šampionátem obavy (ICU, 2012f).

\section{ZÁVĚR}

Lze konstatovat, že experti ve spojitosti s konáním EURO 2012 nejčastěji upozorňovali na následující rizikové fenomény - kriminalitu (at' už násilnou nebo např. ve formě kapesních krádeží), terorismus a incidenty fotbalových chuligánů. Na tyto jevy byla rovněž ze strany organizačních struktur a bezpečnostních složek upřena největší pozornost. Široká škála bezpečnostních opatření a strategií přijatých v souvislosti s konáním turnaje, mezi které patří mj. novelizace trestního zákoníku, zřízení bezpečnostních výborů nebo hraniční kontroly prováděné i na vnitřních hranicích Evropské unie, však zajistila relativně bezpečný průběh fotbalového mistrovství, ačkoli před šampionátem panovaly částečně oprávněné obavy právě z toho, že pořadatelské země nedokážou zajistit $\mathrm{z}$ bezpečnostního hlediska poklidný šampionát. $\mathrm{Z}$ celkového pohledu lze tedy závěrem uvést, že se Polsko a Ukrajina zhostily svého nelehkého úkolu velmi dobře a že se těmto zemím podařilo uspořádat bezpečné fotbalové mistrovství Evropy. Konstatovat lze také skutečnost, že poznatky vyplývající z bezpečnostních opatření při mistrovství Evropy v roce 2012 jsou již zapracovány v materiálech pro následující mistrovství Evropy v kopané, které se uskuteční v roce 2016 ve Francii (viz UEFA, 2014). Zde popsaná rizika během fotbalových utkání a jednotlivá protiopatření mohou být využita $\mathrm{v}$ českém prostředí, nejenom $\mathrm{v}$ př́padě hypotetické snahy o uspořádání mistrovství Evropy v kopané, ale i v prŕípadě opatření během rizikových fotbalových utkání české fotbalové ligy.

\section{LITERATURA}

Bedřich, L. (2006). Fotbal - rituálni hra moderní doby. Brno: Masarykova univerzita.

Děkanovský, J. (2008). Sport, média a mýty. Zlatí hoši, královna bílé stopy a dalši moderní hrdinové. Praha: Dokořán.

Dunning, E., Murphy, P. \& Williams, J. M. (1988): The Roots of Football Hooliganism: An Historical and Sociological Study. Michigan: Routledge/Paul Kegan.

Frosdick, S. \& Marsh, P. (2005): Football Hooliganism. Devon: Willan Publishing.

Giulianotti, R. (1999). Football: A Sociology of the Global Game. Cambridge: Polity Press.

Giulianotti, R., \& Klauser, F. (2010). Security Governance and Sport Mega-events: Toward an Interdisciplinary Research Agenda. Journal of Sport \& Social Issues [online]. roč. 34, č. 1, s. 49-61. Dostupné z: http://jss. sagepub.com/content/34/1/49.full.pdf+html.

Giulianotti, R., \& Klauser, F. (2012). Sport mega-events and ,terrorism': A critical analysis. International Review for the Sociology of Sport [online]. roč. 47, č. 3, s. 307-323. Dostupné z: http://irs.sagepub.com/ content/47/3/307.full.pdf + html.

Jindrová, B., \& Smolík, J. (2009). Sociální práce s fotbalovými fanoušky během mistrovství Evropy 2008. Sociální práce/Sociálna práca. roč. IX, č. 2, s. 119-126.

Jusko, P. (2009). Sociálna práca s mládežou a sociálnopatologické javy. Banská Bystrica: Pedagogická fakulta, $U M B$.

Kasal, J. (2013): Násilí na stadionech jako odraz kultury. Hradec Králové: Gaudeamus.

Kowalska, J. E. (2007). Cały nasz chuligański trud wkładamy w nasz ukochany klub. In: Sport a agresja. Ed. Dziubiński, Z. Warszawa: SALOS, s. 240-247.

Leška, D. (2004). Šport jako socializácia. In Sekot, A. (ed.): Sociální dimenze sportu. Brno: Masarykova univerzita, s. 141157.

Liedel, K., \& Piasecka P. (2012). EURO 2012 Security as a Joint Task of Poland and Ukraine - A Challenge for National and International Security Systems. National Security Bureau [online]. Dostupné z: http://en.bbn.gov. pl/download/3/841/Liedel__Piasecka.pdf.

Lovaš, L. (2010). Agresia a násilie. Psychológia l’udskej agresie a jej podoby v domácom prostredí, v škole, 
v práci, vo väzniciach a športe. Bratislava: Ikar.

Mareš, M., Smolík, J., \& Suchánek, M. (2004). Fotbalovi chuligáni: evropská dimenze subkultury. Brno: Centrum strategických studí́.

Mikšík, O. (2005): Hromadné psychické jevy. (Psychologie hromadného chování). Praha: Karolinum.

Miller, T. a kol. (2001). Playing the World. London: SAGE Publications.

Sekot, A. (2006). Sociologie sportu. Brno: Masarykova univerzita a Paido.

Sekot, A. (2007). Sociologické dimenze sportu. Studia sportiva. Roč. 1, č. 1, s. 66-75.

Sekot, A. (2008). Sociologické problémy sportu. Praha: Grada Publishing.

Slepička, P. (1990). Sportovní diváctví. Praha: Olympia.

Slepička, P. a kol. (2010). Divácká reflexe sportu. Praha: Karolinum.

Smolík, J. (2002). Psychologické aspekty fotbalového diváctví. Brno: Masarykova univerzita.

Smolík, J. (2008). Fotbalové chuligánství. Historie, teorie a politizace fenoménu. Karlovy Vary: VNP.

Smolík, J. (2010). Subkultury mládeže. Uvedeni do problematiky. Praha: Grada Publishing.

Soloviov, V. (2012). Security Challenges and Ukrainian-Polish Cooperation in the Organization of the EURO 2012. National Security Bureau [online]. Dostupné z: http://en.bbn.gov.pl/download/3/842/Soloviov.pdf.

SOS International. (2012). Euro 2012 safety and security report [online]. Dostupné z: http://www.yumpu.com/ en/document/view/3590156/euro-2012-safety-and-security-report-sos-international.

Taylor, I. (1971). „Football Mad“: A Speculative Sociology of Football Hooliganism. In Dunning, E. (ed.). The Sociology of Sport. London: Frank Cass, s. 352-377.

Tilly, Ch. (2006). Politika kolektivního násili. Praha: Sociologické nakladatelství.

Tsoukala, A. (2009). The definition of security threats in the public debate: comparing terrorism and hooliganism in the UK. Challenge: liberty and security, s. 1-10. Dostupné z: http://www.libertysecurity.org/module/pdfs/ CHALLENGE-2009_Tsoukala_2.pdf.

\section{Publicistické zdroje}

Česká tisková kancelář (2012). UEFA dostala od Ukrajiny ujištění, že bezpečnost na Euru zajistí [online]. 1. května 2012. Dostupné z: http://www.sportovninoviny.cz/tema/zpravy/uefa-dostala-od-ukrajiny-ujisteni-zebezpecnost-na-euru-zajisti/788994\&id_seznam $=4876$.

Gazeta Wyborcza (2012). GROM, komandosi, F16, rakiety, kontrwywiad - wszyscy na Euro [online]. 5. června 2012. Dostupné z: http://wyborcza.pl/1,75478,11867149,GROM_komandosi_F16_rakiety_ kontrwywiad__wszyscy.html.

hooligans.cz (2013). Polsko: Historie ,ustawek“ [online]. 30. března 2013. Dostupné z: http://www.hooligans. cz/reports/foreign/46-pol/2613-polsko-historie-ustawek.

Interfax (2010). FBI helping Ukraine train anti-terror action for Euro 2012 [online]. 22. prosince 2010. Dostupné z: http://search.proquest.com/docview/1017683785/fulltext?source=fedsrch\&accountid=16531.

Interfax (2012). Dnipropetrovsk bombers wanted to frustrate Euro 2012 in Ukraine, says SBU [online]. 20. rŕjna 2012. Dostupnéz:http://search.proquest.com/docview/1113854286/fulltext?source=fedsrch\&accountid=16531. Obozrevatel (2012). No violations of public order registered during EURO 2012 final [online]. 2. července 2012. Dostupné z: http://eng.obozrevatel.com/euro-2012/48712-no-violations-of-public-order-registeredduring-euro-2012-final.htm.

\section{Prameny}

Bureš, R. (2005). Přehled Doporučení Rady Evropy pro prevenci a potírání diváckého násilí při sportovních utkáních. In: Prevence diváckého násili při sportovních utkáních. Praha: Ministerstvo vnitra ČR, s. 9-10.

Information Centre Ukraine-2012 (2012a). Police Cooperation Centre starts operation [online]. 6. června 2012. Dostupné z: http://ukraine2012.gov.ua/en/news/239/53857/.

Information Centre Ukraine-2012 (2012b). Euro chronicle: Day eighteen [online]. 26. června 2012. Dostupné z: http://ukraine2012.gov.ua/en/news/182/54813.

Information Centre Ukraine-2012 (2012c). Semi-final match day in Ukraine passes peacefully [online]. 28. června 2012. Dostupné z: http://ukraine2012.gov.ua/en/news/182/54887/.

Information Centre Ukraine-2012 (2012d). Euro-2012 to be guarded by 22,000 policemen [online]. 30. května 2012. Dostupné z: http://ukraine2012.gov.ua/en/news/239/53716/.

Information Centre Ukraine-2012 (2012e). Capital 's police force handled security at Euro successfully [online]. 
11. července 2012. Dostupné z: http://ukraine2012.gov.ua/en/news/239/55157/.

Information Centre Ukraine-2012 (2012f). UEFA: there is no racism in Ukraine [online]. 1. července 2012. Dostupné z: http://ukraine2012.gov.ua/en/news/239/54988/.

Komenda Powiatowa Policji w Legionowie (nedatováno). BÓJKA LUB POBICIE - aspekty prawne [online]. Dostupné z: http://kpplegionowo.policja.waw.pl/portal/ple/37/2195/BOJKA_LUB_POBICIE_aspekty_ prawne.html.

Ministry of Interior (2007a). European Football Championships in 2012 will be held in Poland and Ukraine! [online]. Dostupné z: http://www.msw.gov.pl/portal/en/26/249/European_Football_Championships_in_2012_ will_be_held_in_Poland_and_Ukraine.html.

Ministry of Interior (2007b). Security of EURO 2012 [online]. Dostupné z: http://www.msw.gov.pl/portal/ en/26/248/Security_of_EURO_2012.html.

Ministry of Interior (2012a). The Police Command Centre for EURO 2012 [online]. Dostupné z: http://www. msw.gov.pl/portal/en/1/743/The_Police_Command_Centre_for_EURO_2012.html.

Ministry of Interior (2012b). More security at mass events [online]. Dostupné z: http://www.msw.gov.pl/portal/ en/1/742/More_security_at_mass_events.html.

Ministry of Interior (2012c). Feeling safe during EURO 2012 [online]. Dostupné z: http://www.msw.gov.pl/ portal/en/1/745/Feeling_safe_during_EURO_2012.html.

NPIA (2010): Guidance on Policing Football. Dostupné z: http://www.acpo.police.uk/documents/ uniformed/2010/201008UNGPF01.pdf.

Policja Rzeczypospolitiej Polskiej (2012). Operacja „Hat-Trick 2012” - Bezpieczne EURO 2012 [online]. Dostupné z: http://www.policja.pl/portal/pol/1/78875/Operacja_HatTrick_2012_Bezpieczne_EURO_2012. html.

Policie České republiky (2012a). Informace k EURO 2012 [online]. Dostupné z: http://www.policie.cz/clanek/ informace-k-euro-2012.aspx.

Policie České republiky (2012b). Př́pravy byly dokončeny, do Polska odjeli první policisté [online]. Dostupné z: http://www.policie.cz/clanek/pripravy-byly-dokonceny-do-polska-odjeli-prvni-policiste.aspx.

Policie České republiky (2012c). Opatření běži naplno [online]. Dostupné z: http://www.policie.cz/clanek/ opatreni-bezi-naplno.aspx.

Policie České republiky (2012d). AKT jsou v Polsku úspěšné [online]. Dostupné z: http://www.policie.cz/ clanek/akt-jsou-v-polsku-uspesne.aspx.

Služba Bezpeky Ukrajiny (2011). Pid chas EURO 2012 teroristichni zagrozi zrostut utrichi [online]. Dostupné z: http://www.sbu.gov.ua/sbu/control/uk/publish/article?art_id=108646\&cat_id=108653.

UEFA (2014): Regulations of the UEFA European Football Championship 2014-2016. [online]. Dostupné z: http://www.uefa.com/MultimediaFiles/Download/Regulations/uefaorg/Regulations/02/03/92/81/2039281_ DOWNLOAD.pdf.

Żandarmeria Wojskowa (2012). Czas podsumowań [online]. Dostupné z: http://www.zw.wp.mil.pl/pl/1_1484. html. 